Vol 1. No. 4. Oktober 2021 P-ISSN : 2774-8014. e-ISSN : 2774-7034

\title{
PENERAPAN MODEL PEMBELAJARAN DISCOVERY LEARNING MELALUI PENDEKATAN SAINTIFIK UNTUK MENINGKATKAN HASIL BELAJAR SISWA KELAS II DI SD NEGERI 011 TITIAN RESAK
}

\author{
SUSIYANTI \\ SD Negeri 011 Titian Resak \\ e-mail: susiyanti52@guru.sd.belajar.id
}

\begin{abstract}
ABSTRAK
Bagaimanakah cara agar peserta didik aktif dalam proses pembelajaran dan berfikir kritis dalam mengikuti kegiatan pembelajaran. Model pembelajaran apakah, selain ceramah dan metode penugasan yang bersifat teoritis dan hanya menyalin dari buku teks dalam hal ini hingga terwujud kegiatan pembelajaran yang lebih bermakna. Penelitian ini menggunakan penelitian tindakan (action research) sebanyak tiga siklus. Sasaran penelitian ini adalah siswa kelas II SD Negeri 011 Titian Resak, Data yang diperoleh berupa hasil tes formatif, lembar observasi kegiatan pembelajaran. Dari hasil analis didapatkan bahwa prestasi belajar siswa mengalami peningkatan dari siklus I sampai siklus III yaitu, siklus I $(66,67 \%)$, siklus II $(76,19 \%)$, siklus III $(90,48 \%)$. Kesimpulan dari penelitian ini adalah peningkatan hasil belajar siswa terlihat pada proses pembelajaran pada setiap siklus dengan menggunakan metode Discovery Learning melalui pendekatan saintifik.. Diharapkan siswa kelas II SD Negeri 011 Titian Resak dapat memahami materi kalimat ajakan dengan berorientasi pada keterampilan berpikir tingkat tinggi (higher order thinking skills/ HOTS). Dengan menggunakan model dan pendekatan pembelajaran tersebut dapat digunakan sebagai salah satu motivasi peserta didik aktif dalam proses pembelajaran.
\end{abstract}

Kata Kunci: Discovery Learning, higher order thinking skills /( HOTS), pendekatan saintifik.

\section{PENDAHULUAN}

Kurikulum 2013 merupakan pendekatan pembelajaran yang mengintegrasikan beberapa muatan pelajaran dalam satu pembelajaran utuh yang saling berkaitan. Dalam praktik pembelajaran yang penulis lakukan selama ini, penulis menggunakan buku siswa dan buku guru. dalam praktiknya, penulis mengalami beberapa kesulitan seperti materi dan tugas tidak sesuai dengan latar belakang siswa. Selain itu, penulis masih terfokus pada penguasaan pengetahuan kognitif yang lebih mementingkan hafalan materi. Dengan demikian proses berpikir siswa masih dalam level $\mathrm{C} 1$ (mengingat), memahami (C2), dan C3 (aplikasi). Guru hampir tidak pernah melaksanakan pembelajaran yang berorientasi pada keterampilan berpikir tingkat tinggi (higher order thinking skills/ HOTS).

Salah satu model pembelajaran yang berorientasi pada HOTS dan disarankan dalam implementasi Kurikulum 2013 adalah model pembelajaran berbasis masalah (Discovery Learning). Discovery Learning merupakan model pembelajaran yang mengedepankan strategi pembelajaran dengan menggunakan masalah dari dunia nyata sebagai konteks siswa untuk belajar tentang cara berpikir kritis dan keterampilan pemecahan masalah yang dihadapi dikehidupan sehari- hari, serta untuk memperoleh pengetahuan dan konsep esensial dari materi yang dipelajarinya.

Menurut Richard dalam Roestiyah N.K. (2012, hlm. 20) Model pembelajaran discovery learning merupakan model pembelajaran berpikir kritis serta keterampilan pemecahan masalah melalui tukar pendapat, diskusi, mencoba, agar peserta didik dapat belajar belajar mandiri dengan cara menemukan.

Menurut Ernawati (2017:196-197), berpikir tingkat tinggi atau Higher Order Thinking Skills (HOTS) merupakan cara berpikir yang tidak hanya menghafal namun juga mampu berpikir yang integralistik. 
Menurut Hosnan (2014:34) pendekatan scientific adalah proses pembelajaran yang dirancang agar peserta didik secara aktif melalui tahapan-tahapan mengamati (untuk mengidentifikasi atau menemukan masalah), merumuskan masalah

Permasalahan di lapangan dihadapi membuktikan bahwa suasana kegiatan pembelajaran di kelas kaku serta anak- anak tampak tidak aktif dalam proses pembelajaran sehingga pembelajaran masih kurang maksimal.

Berdasarkan latar belakang permasalahan di atas maka hasil penelitian pembelajaran diperoleh informasi sebagai berikut :

a) Siswa masih kurang aktif dan berfikir kritis dalam mengikuti kegiatan pembelajaran.

b) Kurangnya variasi model pembelajaran, selain ceramah dan metode penugasan yang bersifat teoritis dan hanya menyalin dari buku teks.

Untuk menghadapi permasalahan di atas, siswa harus dibekali keterampilan berpikir tingkat tinggi (higher order thinking skills). Peneliti menggunakan model pembelajaran Discovery Learning. Setelah melaksanakan pembelajaran tematik terpadu dengan model Discovery Learning, peneliti menemukan bahwa proses dan hasil belajar siswa meningkat. Lebih bagus dibandingkan pembelajaran sebelumnya. Ketika model Discovery Learning ini diterapkan pada kelas II yang lain ternyata proses dan hasil belajar siswa sama baiknya. Pada penggunaan model pembelajaran Discovery Learning ini peneliti simpulkan dengan pembelajaran berorientasi HOTS dengan model pembelajaran Discovery Learning siswa termotivasi aktif dan berpikir kritis dalam kegiatan pembelajaran.

\section{METODE PENELITIAN}

Jenis penelitian yang digunakan pada penelitian ini adalah penelitian tindakan kelas. Ningrum (2014: 41) menerangkan bahwa Penelitian Tindakan Kelas (PTK) merupakan penelitian untuk memecahkan permasalahan pembelajaran melalui suatu tindakan dengan tujuan memperbaiki dan meningkatkan kualitas pembelajaran, baik proses maupun hasil belajar siswa. Penelitian ini dilakukan bekerjasama dengan guru kelas dan teman sejawat (observer). Penelitian bertujuan untuk memberikan informasi bagaimana cara untuk meningkatkan keaktifan dan kompetensi kognitif siswa pada mata pelajaran Bahasa Indonesia dengan metode discovery learning. Penelitian tindakan kelas ini merupakan rangkaian dari siklus- siklus yang mengalami peningkatan keaktifan dan hasil belajar siswa.

. Sasaran penelitiaan ini dilaksanakan pada siswa kelas II semester 1 tahun pelajaran 2019/ 2020 di SD Negeri 011 Titian Resak sebanyak 21 orang. Bahan yang digunakan dalam pembelajaran ini adalah materi kelas II untuk tema Hidup Rukun merupakan pembelajaran tematik gabungan KD Bahasa Indonesia, Matematika, dan SBDP. Model pembelajaran yang digunakan dalam pelaksanaan praktik ini adalah menerapkan pembelajaran tematik terpadu dengan model pembelajaran Discovery Learning.

Media pembelajaran yang digunakan dalam penelitian ini adalah (a) gambar hidup Rukun di tempat bermain " untuk didiskripsikan dalam beberapa kalimat. (b) teks percakapam dan (c) lembar kerja siswa (LKPD) tematik. Sedangkan Instrumen yang digunakan dalam praktik ini ada 2 macam yaitu (a) instrumen untuk mengamati proses pembelajaran berupa lembar observasi dan (b) instrumen untuk melihat hasil belajar siswa dengan menggunakan tes tertulis uraian singkat.

\section{HASIL DAN PEMBAHASAN}

Hasil yang dapat dilaporkan dari penelitian ini diuraikan bahwa proses pembelajaran tematik yang dilakukan dengan menerapkan model pembelajaran Descovery Learning dapat menjadikan siswa menjadi lebih aktif merespon pertanyaan dari guru, termasuk mengajukan pertanyaan pada guru maupun temannya. Aktifitas pembelajaran yang dirancang sesuai sintak Descovery Learning megharuskan siswa aktif selama proses pembelajaran Dalam pembelajaran sebelumnya yang dilakukan penulis tanpa berorientasi HOTS suasana kelas cenderung sepi dan serius. 
Fokus guru adalah bagaimana siswa dapat menyelesikan soal yang disajikan; kurang peduli pada proses berpikir siswa. Tak hanya itu, materi pembelajaran yang selama ini selalu disajikan dengan pola deduktif (diawali dengan ceramah teori tentang materi yang dipelajari, pemberian tugas, dan pembahasan), membuat siswa cenderung menghapalkan teori. Pengetahuan yang diperoleh siswa adalah apa yang diajarkan oleh guru. Berbeda kondisinya dengan pembelajaran tematik berorientasi HOTS dengan menerapkan Descovery Learning ini meuntut kemampuan siswa untuk berpikir kritis.

Kurangnya variasi model pembelajaran, selain ceramah dan metode penugasan yang bersifat teoritis dan hanya menyalin dari buku teks. minat membaca dalam keterampilan berbahasa Indonesia dapat memberikan pengaruh yang positif sehingga siswa merasakan pada dirinya ada perubahan berupa kemajuan dalam belajarnya karena dirinya telah termotivasi sehingga minat membaca meningkat dan bergairah untuk belajar. Descovery Learning yang diterapkan dengan menyajikan teks tulis dan video berisi permasalahan kontekstual mampu mendorong siswa merumuskan pemecahan masalah. penulis melaksanakan pembelajaran sesuai dengan buku guru dan buku siswa. Meskipun permasalahan yang disajikan dalam buku teks kadang kala kurang sesuai dengan kehidupan sehari-hari siswa, tetap saja penulis gunakan. Jenis teks yang digunakan juga hanya pada teks tulis dari buku teks. Dengan menerapkan Descovery Learning, siswa tak hanya belajar dari teks tulis, tetapi juga dari video serta diberi kesempatan terbuka untuk mencari data, materi dari sumber lainnya.

\section{A. Hasil}

Masalah yang dihadapi pada penelitian ini terutama adalah siswa belum terbiasa belajar dengan model Descovery Learning. Dengan tujuan untuk mendapat nilai ulangan yang baik guru selalu mengunakan metode ceramah, siswa pun merasa lebih percaya diri menghadapi ulangan (penilaian) setelah mendapat penjelasan guru melalui ceramah.

Masalah lainnya adalah guru tidak mempunyai kompetensi yang memadai untuk membuat video pembelajaran. Padahal selain sebagai media pembelajaran,Video juga merupakan bentuk teks audiovisual yang juga harus disajikan sesuai dengan rumusan kompetensi dasar.

Agar siswa yakin bahwa pembelajaran tematik dengan Descovery Learning dapat membantu mereka lebih menguasai materi pembelajaran, guru memberi penjelasan sekilas tentang apa, bagaimana, mengapa, dan manfaat belajar berorientasi pada keterampilan berpikir tingkat tinggi (higher order thinking skills/HOTS). Pemahaman dan kesadaran akan pentingnya HOTS ajkan membuat siswa termotivasi untuk mengikuti pembelajaran. Selain itu, kesadaran bahwa belajar bukan sekadar menghafal teori dan konsep akan membuat siswa mau belajar dengan HOTS.

Kekurangmampuan guru membuat video pembelajaran dapat diatasi dengan mengunduh video sesuai dengan KD yang akan dibelajarkan baik dari youtube maupun dari Rumah Belajar. Dengan demikian, selain menerapkan kegiatan literasi baca - tulis, siswa juga dapat meningkatkan literasi digitalnya.

Untuk menghitung persentase ketuntasan belajar digunakan rumus sebagai berikut: Peneliti melakukan penjumlahan nilai yang diperoleh siswa, yang selanjutnya dibagi dengan jumlah siswa yang ada di kelas tersebut sehingga diperoleh rata-rata tes formatif. Untuk menghitung persentase ketuntasan belajar digunakan rumus sebagai barikut:

$$
\begin{aligned}
& \bar{X}=\frac{\sum X}{\sum N} \\
& \text { Dengan }: \bar{X} \quad=\text { Nilai rata-rata } \\
& \Sigma \mathrm{X}=\text { Jumlah semua nilai siswa } \\
& \Sigma \mathrm{N}=\text { Jumlah siswa } \\
& P=\frac{\sum \text { Siswa.yang.tuntas.belajar }}{\sum \text { Siswa }} \times 100 \%
\end{aligned}
$$


Data penelitian berupa pengamatan proses belajar dan penilaian guru pada akhir pembelajaran berupa data tes formatif siswa pada setiap siklus.

\section{Siklus I}

\section{a. Tahap Perencanaan}

Pada tahap ini peneliti mempersiapkan perangkat pembelajaran yang terdiri dari rencana pelajaran 1, LKS 1, soal tes formatif 1 dan alat-alat pengajaran yang mendukung.

b. Tahap Kegiatan dan Pelaksanaan

Pelaksanaan kegiatan belajar mengajar untuk siklus I dilaksanakan pada tanggal 26 Agustus 2019 di Kelas II dengan jumlah siswa 21 siswa. Dalam hal ini peneliti bertindak sebagai guru. Adapun proses belajar mengajar mengacu pada rencana pelajaran yang telah dipersiapkan. Pengamatan (observasi) dilaksanakan bersamaan dengan pelaksaaan belajar mengajar. Pada akhir proses belajar mengajar siswa diberi tes formatif I dengan tujuan untuk mengetahui tingkat keberhasilan siswa dalam proses belajar mengajar yang telah dilakukan. Adapun data hasil penelitian pada siklus I adalah sebagai berikut:

Data tes formatif untuk mengetahui peningkatan hasil belajar belajar siswa setelah diterapkan belajar dengan model pembelajaran Discovery Learning adalah sebagai berikut:

Tabel 1. Distribusi Nilai Tes Pada Siklus I

\begin{tabular}{|c|c|c|c|c|c|c|c|}
\hline \multirow{2}{*}{$\begin{array}{l}\text { No. } \\
\text { Urut }\end{array}$} & \multirow{2}{*}{ Skor } & \multicolumn{2}{|c|}{ Keterangan } & \multirow{2}{*}{$\begin{array}{l}\text { No. } \\
\text { Urut }\end{array}$} & \multirow{2}{*}{ Skor } & \multicolumn{2}{|c|}{ Keterangan } \\
\hline & & $\mathrm{T}$ & TT & & & $\mathrm{T}$ & $\mathrm{TT}$ \\
\hline 1 & 70 & $\sqrt{ }$ & & 12 & 30 & & $\sqrt{ }$ \\
\hline 2 & 50 & & $\sqrt{ }$ & 13 & 70 & $\sqrt{ }$ & \\
\hline 3 & 80 & $\sqrt{ }$ & & 14 & 100 & $\sqrt{ }$ & \\
\hline 4 & 60 & & $\sqrt{ }$ & 15 & 70 & $\sqrt{ }$ & \\
\hline 5 & 40 & & $\sqrt{ }$ & 16 & 70 & $\sqrt{ }$ & \\
\hline 6 & 80 & $\sqrt{ }$ & & 17 & 70 & $\sqrt{ }$ & \\
\hline 7 & 70 & $\sqrt{ }$ & & 18 & 80 & $\sqrt{ }$ & \\
\hline 8 & 60 & & $\sqrt{ }$ & 19 & 60 & & $\sqrt{ }$ \\
\hline 9 & 80 & $\sqrt{ }$ & & 20 & 80 & $\sqrt{ }$ & \\
\hline 10 & 70 & $\sqrt{ }$ & & 21 & 80 & $\sqrt{ }$ & \\
\hline 11 & 60 & & $\sqrt{ }$ & Jumlah & 710 & 8 & 2 \\
\hline Jumlah & 730 & 6 & 5 & & & & \\
\hline \multicolumn{8}{|c|}{$\begin{array}{l}\text { Jumlah Skor } 1440 \\
\text { Jumlah Skor Maksimal Ideal } 2100 \\
\text { Rata-Rata Skor Tercapai } 68,57\end{array}$} \\
\hline
\end{tabular}

$\begin{array}{lll}\text { Keterangan: } & \text { T } & \text { : Tuntas } \\ & \text { TT } & : \text { Tidak Tuntas } \\ & \text { Jumlah siswa yang tuntas } & : 14 \\ & \text { Jumlah siswa yang belum tuntas } & : 7\end{array}$


Tabel 2. Rekapitulasi Hasil Tes Pada Siklus I

\begin{tabular}{|c|l|c|}
\hline No & \multicolumn{1}{|c|}{ Uraian } & Hasil Siklus I \\
\hline 1 & Nilai rata-rata tes formatif & 68,57 \\
2 & Jumlah siswa yang tuntas belajar & 14 \\
3 & Persentase ketuntasan belajar & 66,67 \\
\hline
\end{tabular}

Dari tabel di atas dapat dijelaskan bahwa dengan menerapkan model pembelajaran discovery learning di diperoleh nilai rata-rata hasil belajar belajar siswa adalah 68,57 dan ketuntasan belajar mencapai $66,67 \%$ atau ada 14 siswa dari 21 siswa sudah tuntas belajar. Hasil tersebut menunjukkan bahwa pada siklus pertama secara klasikal siswa belum tuntas belajar, karena siswa yang memperoleh nilai $\geq 65$ hanya sebesar $66,67 \%$ lebih kecil dari persentase ketuntasan yang dikehendaki yaitu sebesar $85 \%$. Hal ini disebabkan karena siswa masih merasa baru dan belum mengerti apa yang dimaksudkan dan digunakan guru dengan menerapkan model pembelajaran Discovery Learning.

\section{Siklus II}

a. Tahap perencanaan

Pada tahap ini peneliti mempersiapkan perangkat pembelajaran yang terdiri dari rencana pelajaran 2, LKS, 2, soal tes formatif II dan alat-alat pengajaran yang mendukung.

b. Tahap kegiatan dan pelaksanaan

Pelaksanaan kegiatan belajar mengajar untuk siklus II dilaksanakan pada tanggal 2 September 2019 di Kelas II dengan jumlah siswa 21 siswa. Dalam hal ini peneliti bertindak sebagai guru. Adapun proses belajar mengajar mengacu pada rencana pelajaran dengan memperhatikan revisi pada siklus I, sehingga kesalahan atau kekurangan pada siklus I tidak terulang lagi pada siklus II. Pengamatan (observasi) dilaksanakan bersamaan dengan pelaksanaan belajar mengajar.

Pada akhir proses belajar mengajar siswa diberi tes formatif II dengan tujuan untuk mengetahui tingkat keberhasilan siswa dalam proses belajar mengajar yang telah dilakukan. Instrumen yang digunakan adalah tes formatif II. Adapun data hasil penelitian pada siklus II adalah sebagai berikut.

Tabel 3. Distribusi Nilai Tes Pada Siklus II

\begin{tabular}{|c|c|c|c|c|c|c|c|}
\hline \multirow{2}{*}{$\begin{array}{c}\text { No. } \\
\text { Urut }\end{array}$} & \multirow{2}{*}{ Skor } & \multicolumn{2}{|c|}{ Keterangan } & \multirow{2}{*}{ No. } & \multirow{2}{*}{ Skor } & \multicolumn{2}{|c|}{ Keterangan } \\
\cline { 7 - 9 } & & $\mathrm{T}$ & $\mathrm{TT}$ & Urut & & $\mathrm{T}$ & $\mathrm{TT}$ \\
\hline 1 & 80 & $\sqrt{ }$ & & 12 & 70 & $\sqrt{ }$ & \\
\hline 2 & 70 & $\sqrt{ }$ & & 13 & 60 & & $\sqrt{ }$ \\
\hline 3 & 90 & $\sqrt{ }$ & & 14 & 90 & $\sqrt{ }$ & \\
\hline 4 & 60 & & $\sqrt{ }$ & 15 & 90 & $\sqrt{ }$ & \\
\hline 5 & 50 & & $\sqrt{ }$ & 16 & 80 & $\sqrt{ }$ & \\
\hline 6 & 60 & & $\sqrt{ }$ & 17 & 80 & $\sqrt{ }$ & \\
\hline 7 & 70 & $\sqrt{ }$ & & 18 & 80 & $\sqrt{ }$ & \\
\hline 8 & 80 & $\sqrt{ }$ & & 19 & 60 & & $\sqrt{ }$ \\
\hline 9 & 80 & $\sqrt{ }$ & & 20 & 80 & $\sqrt{ }$ & \\
\hline 10 & 70 & $\sqrt{ }$ & & 21 & 70 & $\sqrt{ }$ & \\
\hline 11 & 80 & $\sqrt{ }$ & & Jumlah & 760 & 8 & 2 \\
\hline
\end{tabular}


Keterangan: $\quad \mathrm{T}$

TT

Jumlah siswa yang tuntas

Jumlah siswa yang belum tuntas

Klasikal
: Tuntas

: Tidak Tuntas

$: 16$

$: 5$

: Belum tuntas

Tabel 4. Rekapitulasi Hasil Tes Pada Siklus II

\begin{tabular}{|c|l|c|}
\hline No & \multicolumn{1}{|c|}{ Uraian } & Hasil Siklus II \\
\hline 1 & Nilai rata-rata tes formatif & 73,81 \\
2 & Jumlah siswa yang tuntas belajar & 16 \\
3 & Persentase ketuntasan belajar & 76,19 \\
\hline
\end{tabular}

Dari tabel di atas diperoleh nilai rata-rata hasil belajar belajar siswa adalah 73,81 dan ketuntasan belajar mencapai $76,19 \%$ atau ada 16 siswa dari 21 siswa sudah tuntas belajar. Hasil ini menunjukkan bahwa pada siklus II ini ketuntasan belajar secara klasikal telah mengalami peningkatan sedikit lebih baik dari siklus I. Adanya peningkatan hasil belajar siswa ini karena setelah guru menginformasikan bahwa setiap akhir pelajaran akan selalu diadakan tes sehingga pada pertemuan berikutnya siswa lebih termotivasi untuk belajar. Selain itu siswa juga sudah mulai mengerti apa yang dimaksudkan dan diinginkan guru dengan menerapkan model pembelajaran Discovery Learning.

\section{Siklus III}

a. Tahap Perencanaan

Pada tahap ini peneliti mempersiapkan perangkat pembelajaran yang terdiri dari rencana pelajaran 3, LKS 3, soal tes formatif 3 dan alat-alat pengajaran yang mendukung.

b. Tahap kegiatan dan pengamatan

Pelaksanaan kegiatan belajar mengajar untuk siklus III dilaksanakan pada tanggal 10 Oktober 2019 di Kelas II dengan jumlah siswa 21 siswa. Dalam hal ini peneliti bertindak sebagai guru. Adapun proses belajar mengajar mengacu pada rencana pelajaran dengan memperhatikan revisi pada siklus II, sehingga kesalahan atau kekurangan pada siklus II tidak terulang lagi pada siklus III. Pengamatan (observasi) dilaksanakan bersamaan dengan pelaksanaan belajar mengajar.

Pada akhir proses belajar mengajar siswa diberi tes formatif III dengan tujuan untuk mengetahui tingkat keberhasilan siswa dalam proses belajar mengajar yang telah dilakukan. Instrumen yang digunakan adalah tes formatif III. Adapun data hasil penelitian pada siklus III adalah sebagai berikut.

Tabel 5. Rekapitulasi Hasil Tes Pada Siklus III

\begin{tabular}{|c|c|c|c|c|c|c|c|}
\hline \multirow{2}{*}{$\begin{array}{l}\text { No. } \\
\text { Urut }\end{array}$} & \multirow{2}{*}{ Skor } & \multicolumn{2}{|c|}{ Keterangan } & \multirow{2}{*}{$\begin{array}{l}\text { No. } \\
\text { Urut }\end{array}$} & \multirow{2}{*}{ Skor } & \multicolumn{2}{|c|}{ Keterangan } \\
\hline & & $\mathrm{T}$ & TT & & & $\mathrm{T}$ & TT \\
\hline 1 & 80 & $\sqrt{ }$ & & 12 & 70 & $\sqrt{ }$ & \\
\hline 2 & 90 & $\sqrt{ }$ & & 13 & 80 & $\sqrt{ }$ & \\
\hline 3 & 90 & $\sqrt{ }$ & & 14 & 100 & $\sqrt{ }$ & \\
\hline 4 & 60 & & $\sqrt{ }$ & 15 & 90 & $\sqrt{ }$ & \\
\hline 5 & 90 & $\sqrt{ }$ & & 16 & 90 & $\sqrt{ }$ & \\
\hline 6 & 90 & $\sqrt{ }$ & & 17 & 80 & $\sqrt{ }$ & \\
\hline 7 & 90 & $\sqrt{ }$ & & 18 & 90 & $\sqrt{ }$ & \\
\hline 8 & 80 & $\sqrt{ }$ & & 19 & 80 & $\sqrt{ }$ & \\
\hline 9 & 60 & & $\sqrt{ }$ & 20 & 100 & $\sqrt{ }$ & \\
\hline 10 & 80 & $\sqrt{ }$ & & 21 & 80 & $\sqrt{ }$ & \\
\hline 11 & 80 & $\sqrt{ }$ & & Jumlah & 860 & 10 & - \\
\hline Jumlah & 890 & 9 & 2 & & & & \\
\hline
\end{tabular}


Jumlah Skor 1750
Jumlah Skor Maksimal Ideal 2100
Rata-Rata Skor Tercapai 83,33

Keterangan: $\mathrm{T}$

TT

Jumlah siswa yang tuntas

Jumlah siswa yang belum tuntas

Klasikal
: Tuntas

: Tidak Tuntas

$: 19$

$: 2$

: Tuntas

Tabel 6. Rekapitulasi Hasil Tes Pada Siklus III

\begin{tabular}{|c|l|c|}
\hline No & \multicolumn{1}{|c|}{ Uraian } & Hasil Siklus III \\
\hline 1 & Nilai rata-rata tes formatif & 83,33 \\
2 & Jumlah siswa yang tuntas belajar & 19 \\
3 & Persentase ketuntasan belajar & 90,48 \\
\hline
\end{tabular}

Berdasarkan tabel diatas diperoleh nilai rata-rata tes formatif sebesar 83,33 dan dari 21 siswa yang telah tuntas sebanyak 19 siswa dan 2 siswa belum mencapai ketuntasan belajar. Maka secara klasikal ketuntasan belajar yang telah tercapai sebesar 90,48\% (termasuk kategori tuntas). Hasil pada siklus III ini mengalami peningkatan lebih baik dari siklus II. Adanya peningkatan hasil belajar pada siklus III ini dipengaruhi oleh adanya peningkatan kemampuan guru dalam menerapkan belajar dengan model pembelajaran discovery learning. sehingga siswa menjadi lebih terbiasa dengan pembelajaran seperti ini sehingga siswa lebih mudah dalam memahami materi yang telah diberikan.

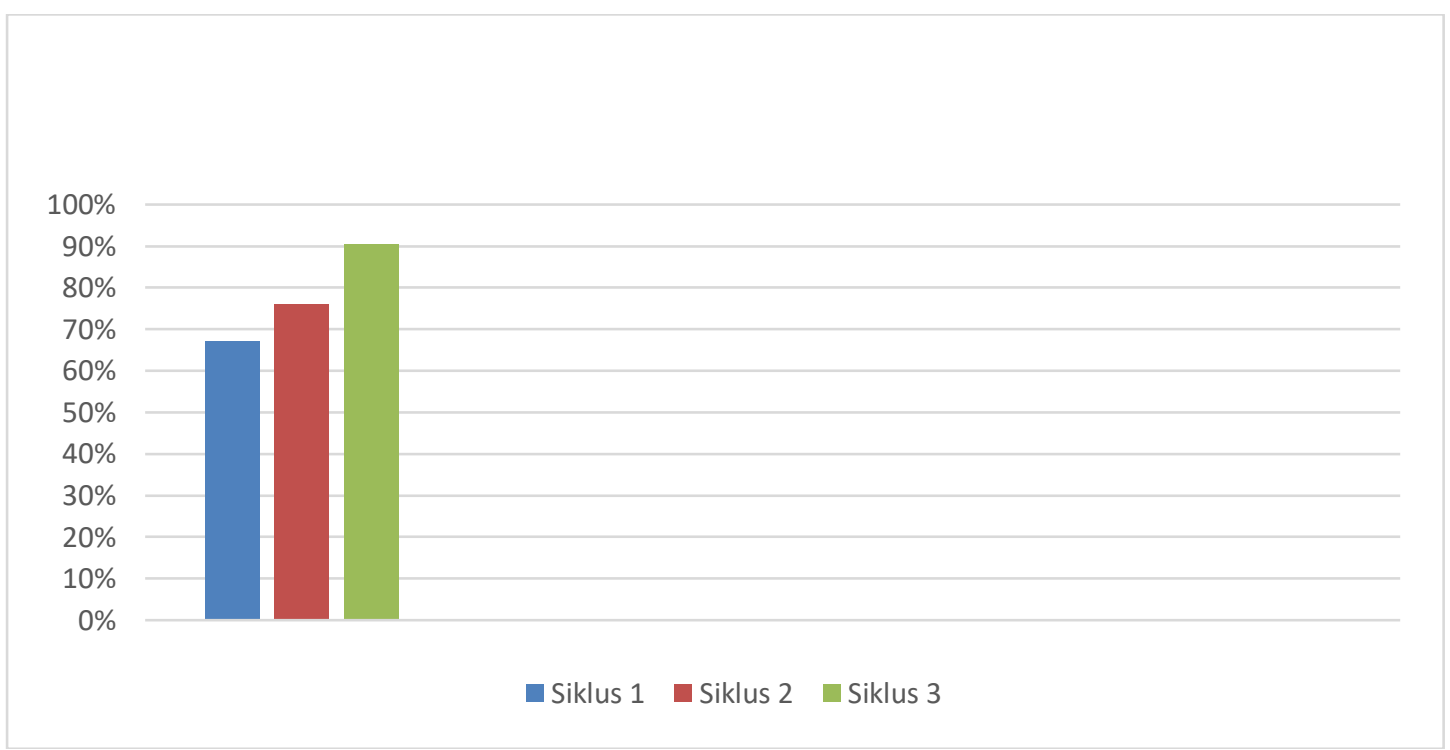

\section{Gambar 1. Grafik Persentase Peningkatan}

Dari hasil analis didapatkan bahwa prestasi belajar siswa mengalami peningkatan dari siklus I sampai siklus III yaitu, siklus I (66,67\%), siklus II (76,19\%), siklus III $(90,48 \%)$.

Kesimpulan dari penelitian ini adalah peningkatan hasil belajar siswa terlihat pada proses pembelajaran pada setiap siklus dengan menggunakan metode Discovery Learning melalui pendekatan saintifik. Diharapkan siswa kelas II SD Negeri 011 Titian Resak dapat memahami materi kalimat ajakan dengan berorientasi pada keterampilan berpikir tingkat tinggi (higher order thinking skills/ HOTS). Dengan menggunakan model dan pendekatan pembelajaran tersebut dapat digunakan sebagai salah satu motivasi peserta didik aktif dalam proses pembelajaran. 


\section{B. Pembahasan}

Penelitian ini menggunakan Penelitian Tindakan Kelas (PTK). Menurut Arikunto, dkk (2006), Penelitian tindakan kelas merupakan suatu pencermatan terhadap kegiatan tindakan yang sengaja dimunculkan dan terjadi dalam sebuah kelas secara bersama. Adapun tujuan utama dari PTK adalah untuk memperbaiki/meningkatkan praktik pembelajaran secara berkesinambungan, sedangkan tujuan penyertaannya adalah menumbuhkan budaya meneliti di kalangan guru (Mukhlis, 2000: 5). Sesuai dengan jenis penelitian yang dipilih, yaitu penelitian tindakan, maka penelitian ini menggunakan model penelitian tindakan dari Kemmis dan Taggart (dalam Sugiarti, 1997: 6), yaitu berbentuk spiral dari sklus yang satu ke siklus yang berikutnya. Setiap siklus meliputi planning (rencana), action (tindakan), observation (pengamatan), dan reflection (refleksi).

Metode pengumpulan data dapat dilakukan dengan cara: (1) Observasi (pengamatan langsung) oleh peneliti tentang aktivitas dan sikap siswa pada saat proses pembelajaran. Observasi atau pengamatan adalah usaha sadar untuk mengumpulkan data yang dilakukan secara sistematis dengan prosedur yang standar (Suharsimi Arikunto, 2002:225).

Model Pembelajaran discovery learning didefinisikan sebagai proses pembelajaran yang terjadi bila pembelajar tidak disajikan dengan pelajaran dalam bentuk finalnya, tetapi melalui proses menemukan (Saefuddin \& Berdiati, 2014, hlm. 56).

Menurut Daryanto, (2014:51) mengungkapkan bahwa pembelajaran dengan pendekatan adalah suatu proses pembelajaran yang dirancang agar peserta didik aktif melalui tahapan merumuskan masalah, merumuskan hipótesis, mengumpulkan data, menganalisis data, membuat kesimpulan dan mengkomunikasikan konsep.

\section{KESIMPULAN}

Berdasarkan pada hasil pembahasan, maka dapat dikemukakan bahwa proses pembelajaran dengan menggunakan metode discovery learning dan pendekatan saintifik pada peserta didik kelas II SD Negeri 011 Titian Resak dapat dapat disimpulkan sebagai berikut :

1. Pembelajaran dengan Model pembelajaran discovery learning menjadikan siswa aktif dan berpikir kritis dalam pemecahan masalah di kegiatan pembelajaran.

2. Dengan Model pembelajaran discovery menambah variasi pemilihan model pembelajaran, selain ceramah dan metode penugasan yang bersifat teoritis dan hanya menyalin dari buku teks.

Dalam melakukan transfer pengetahuan, berpikir kritis, dan pemecahan masalah. Dengan penyusunan rencana pelaksanaan pembelajaran (RPP) secara sistematis dan cermat, pembelajaran tematik dengan model pembelajaran Descovery Learning yang dilaksanakan tidak sekadar berorientasi HOTS.

Dengan hasil pelaksanaan ini, disarankan kepada semua pendidik tidak hanya mengajar dengan mengacu pada buku siswa dan buku guru serta jaring-jaring tema yang telah disediakan, tetapi berani melakukan berbagai inovasi pembelajaran tematik berorientasi HOTS yang kontekstual sesuai dengan latar belakang siswa dan situasi dan kondisi sekolahnya. Hal ini akan membuat pembelajaran lebih bermakna dan menarik. Siswa diharapkan untuk menerapkan kemampuan berpikir tingkat tinggi dalam belajar, tidak hanya terbatas pada hafalan teori.

\section{DAFTAR PUSTAKA}

Arikunto, Suharsimi. (1998). Prosedur Penelitian Suatu Pendekatan Praktek. Jakarta: Rineksa Cipta

Daryanto. (2014). Pendekatan Pembelajaran Saintifik Kurikulum 2013. Yogyakarta: Penerbit Gava Media

Ernawati. (2017). Berpikir Tingkat Tinggi atau Higher Order Thinking Skills (HOTS). Hal.196-197.

Hosnan, M. (2014). pendekatan scientific dan kontekstual dalam pembelajaran abad 21. Jakarta : Ghalia Indonesia 
Kemmis, S. dan Mc. Taggart, R. (1988). The Action Research Planner. Victoria Dearcin University Press.

Mukhlis, Abdul. (Ed). (2000). Penelitian Tindakan Kelas. Makalah Panitia Pelatihan Penulisan Karya Ilmiah untuk Guru-guru se-Kabupaten Tuban.

N.K. Roestiyah (2012). Srategi Belajar Mengajar. Jakarta: PT Rineka Cipta.

Saefuddin, A. \& Berdiati, I. (2014). Pemelajaran Efektif. Bandung: PT Remaja Rosdakarya. 